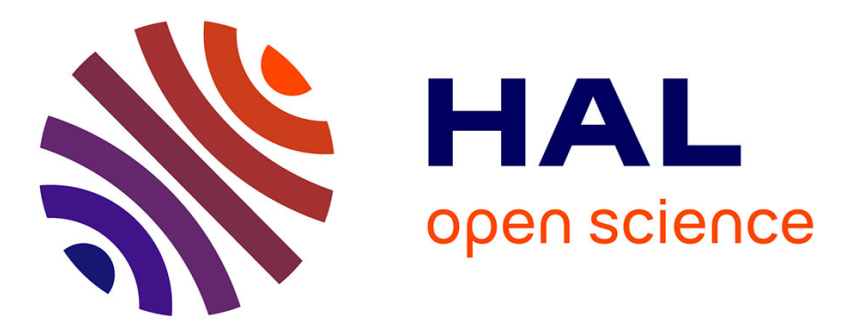

\title{
Dopant-Driven Nanostructured Loose-Tube SnO2 Architectures: Alternative Electrocatalyst Supports for Proton Exchange Membrane Fuel Cells
}

\author{
Sara Cavaliere, Surya Subianto, Iuliia Savych, Monique Tillard, Deborah
} Jones, Jacques Roziere

\section{To cite this version:}

Sara Cavaliere, Surya Subianto, Iuliia Savych, Monique Tillard, Deborah Jones, et al.. DopantDriven Nanostructured Loose-Tube SnO2 Architectures: Alternative Electrocatalyst Supports for Proton Exchange Membrane Fuel Cells. Journal of Physical Chemistry C, 2013, pp.18298-18307. 10.1021/jp404570d. hal-00903703

\section{HAL Id: hal-00903703 https://hal.science/hal-00903703}

Submitted on 7 Apr 2014

HAL is a multi-disciplinary open access archive for the deposit and dissemination of scientific research documents, whether they are published or not. The documents may come from teaching and research institutions in France or abroad, or from public or private research centers.
L'archive ouverte pluridisciplinaire HAL, est destinée au dépôt et à la diffusion de documents scientifiques de niveau recherche, publiés ou non, émanant des établissements d'enseignement et de recherche français ou étrangers, des laboratoires publics ou privés. 


\section{Dopant-driven Nanostructured Loose-Tube $\mathrm{SnO}_{2}$}

\section{Architectures: Alternative Electrocatalyst Supports}

\section{for Proton Exchange Membrane Fuel Cells}

Sara Cavaliere, Surya Subianto, Iuliia Savych, Monique Tillard, Deborah J. Jones*, Jacques

\section{Rozière}

Institut Charles Gerhardt, UMR CNRS 5253 Agrégats Interfaces et Matériaux pour 1'Energie, Université Montpellier 2, 34095 Montpellier Cedex 5 (France) 
ABSTRACT: A novel Niobium-doped $\mathrm{SnO}_{2}$ nanofibres with a complex loose-tube (fiber-in tube) morphology containing a solid fibre within a hollow shell has been prepared by conventional, single-needle electrospinning. The formation mechanism of such 1D architectures has been elucidated, showing the role of the niobium dopant in driving the morphology of electrospun tin oxide from dense fibres towards the loose-tube morphology by enhancing the Kirkendall effect where precursor salts diffuse to the fibre surface during calcination. The role of other parameters such as the heating rate and precursor concentration has also been studied, which would enable morphological control of the nanofibres through variation of these parameters which would alter the dominant mechanism of hollow fibre formation. The materials obtained have been characterized by electron microscopy, thermo-gravimetric analysis, Raman spectroscopy, XPS, and XRD. The loose-tube morphology materials have been further functionalised by depositing Pt nanoparticles prepared by a microwave assisted polyol method, where electrical conductivity and specific surface area measurements as well as accelerated corrosion tests and electrochemical measurements show that $\mathrm{Nb}$ doped $\mathrm{SnO}_{2}$ loose-tubes are promising electrocatalyst supports for proton exchange membrane fuel cells.

KEYWORDS: tin oxide, niobium doping, hollow fibers, electrospinning. 


\section{INTRODUCTION}

Tin oxide-based materials have received considerable attention in the field of energy storage and conversion as electrode materials for a wide range of applications, from lithium ion batteries ${ }^{1,2}$, dye-sensitized solar cells $s^{3,4}$ to sensors ${ }^{5}$ and optoelectronics ${ }^{6}$. Recently, $\mathrm{SnO}_{2}$ has also been used as alternative material to conventional supports for electrocatalysts in Proton Exchange Membrane Fuel Cells (PEMFC) $)^{7,8}$ in an approach attracting increasing interest to remediate the corrosion of conventional carbon support materials. This corrosion leads to consumption of carbon, with a concomitant significant reduction of electrode porosity ${ }^{9}$, as well as de-anchoring of catalyst particles, their aggregation or loss. Conducting oxides ${ }^{10,11}$ including $\mathrm{SnO}_{2}{ }^{12,13}$ are amongst candidate supports to replace carbon.

In particular, one-dimensional (1D) nanostructured $\mathrm{SnO}_{2}$ such as nanofibers and nanotubes are of particular importance with their potentially unique electronic and structural properties ${ }^{14}$. However, facile preparation of high-order nanostructured materials is not a trivial exercise. Several synthetic routes such as hydrothermal ${ }^{15}$, microwave-assisted $^{16}$, templating ${ }^{17}$, and gas-phase methods ${ }^{18}$ have been proposed, but they often require strict synthetic conditions or complicated procedures. An attractive alternative route is via electrospinning, which has emerged as a versatile and efficient method to fabricate organic and inorganic $1 \mathrm{D}$ materials ${ }^{19,20}$. $\mathrm{SnO}_{2}$ hollow fibers or nanotubes are generally achieved by using multi-step processes and/or multiple-needles: for instance, coaxial electrospinning, where phase separation between liquid phases is the main driver behind core/sheath and the derived hollow structures ${ }^{21}$, and electrospinning of sacrificial template fibers followed by deposition of materials at the surface ${ }^{22}$. Recently, the preparation of $\mathrm{SnO}_{2}$ hollow structures by single-needle electrospinning has been reported, but under rather specific conditions, and without variation or control of the morphologies ${ }^{23,24,25}$. 
Here we describe the fabrication and formation mechanism of complex hollow 1D "fiber-intube" structures, by the development of a one-pot, conventional, single-needle electrospinning method. The variation in morphology from dense fibers to "loose-tubes" (to borrow terminology from fiber optic cables, where a fiber is located non-concentrically within a loose external sheath) can be controlled through doping and post-synthesis thermal treatment of the electrospun materials. To the best of our knowledge, neither preparation of loose-tube architectures nor studies regarding the effect of dopants on $\mathrm{SnO}_{2}$ fiber morphology has been previously reported. Doping with niobium, antimony and tantalum has been demonstrated to be a simple and effective way to induce high n-type conductivity of tin oxide ${ }^{26}$. In particular, the enhanced charge transfer in $\mathrm{Nb}$ doped $\mathrm{SnO}_{2}$ materials has shown a marked effect on electrocatalytic ${ }^{13}$, gas sensing ${ }^{27}$ and optoelectronic ${ }^{28}$ properties. Furthermore, the niobium is known to play a fundamental role in directing $\mathrm{SnO}_{2}$ morphology, by inhibiting particle growth and producing materials with high surface area ${ }^{29}$. In the present work, it was found that the addition of niobium did not merely increase the electronic conductivity of $\mathrm{SnO}_{2}$, but it also produced a very significant effect on the fiber morphology: the influence on the particle growth affected the nanostructure of that material, giving rise to a unique "loose-tube" architecture. Furthermore, the electronic conductivity and specific surface area of these materials, as well as their low propensity to electrochemical corrosion and the high electrochemically active surface area of Pt nanoparticle functionalized materials, provide promising properties for application of $\mathrm{Pt} / \mathrm{Nb}-\mathrm{SnO}_{2}$ loose-tube fibers in PEMFC electrodes. 


\section{EXPERIMENTAL SECTION}

Electrospinning of $\mathrm{SnO}_{2}$ based materials 0.27 to $1.50 \mathrm{mg}$ of tin(II) chloride ( $98 \%$, SigmaAldrich) was dissolved in $5.7 \mathrm{~mL}$ of absolute ethanol (puriss., Sigma-Aldrich) and stirred until it was completely dissolved. For niobium doped materials, niobium(V) chloride (98 \% min., Merck) (0.5 to $10 \%$ at doping) was added to this solution. A second solution was prepared by dissolving 0.8 $\mathrm{g}$ of polyvinylpyrrolidone (average $\mathrm{M}_{\mathrm{w}} \sim 1,300,000$, Aldrich) in $3.1 \mathrm{~mL}$ of $\mathrm{N}, \mathrm{N}-$ dimethylformamide (98 \% min., Fluka). The two solutions were then mixed, and stirred for $30 \mathrm{~min}$ to obtain a homogeneous solution. The final solution was electrospun using the following settings: $15 \mathrm{kV}$ applied voltage, $10 \mathrm{~cm}$ needle-collector distance and a flow rate of $0.4 \mathrm{~mL} \mathrm{~h}^{-1}$. The electrospun fibers were removed from the aluminum collector and calcined at $600{ }^{\circ} \mathrm{C}$ for $4 \mathrm{~h}$ in air with a heating rate from 1 to $10{ }^{\circ} \mathrm{C} \mathrm{min}^{-1}$.

Characterization of $\mathrm{SnO}_{2}$ based materials The nanofiber morphology was analyzed by SEM using a Hitachi S-4800 scanning electron microscope and a FEI Quanta FEG 200, by TEM using a JEOL 1200 EXII transmission electron microscope operating at $120 \mathrm{kV}$ equipped with a CCD camera SIS Olympus Quemesa (11 million pixels) and by using a HRTEM JEM - 2200FS JEOL equipped with energy-dispersive spectroscopy analysis (EDS). The samples were suspended in ethanol and sonicated before deposition onto carbon coated copper grids (Agar) for TEM analyses. For cross-sectional TEM, samples were prepared by embedding them in an epoxy resin followed by drying at $80{ }^{\circ} \mathrm{C}$ for $24 \mathrm{~h}$. Microtomed sections of ca $80-100 \mathrm{~nm}$ thickness, prepared using a Reichert ultramicrotome, were deposited on copper grids.

Powder X-ray diffraction (XRD) patterns were recorded at room temperature in BraggBrentano configuration using a PANAlytical X'pert diffractometer, equipped with a hybrid monochromator, operating with $\mathrm{CuK}_{\alpha}$ radiation $(\lambda=1.541 \AA)$, and using a scan rate of $0.001^{\circ}$ per 
second within the $2 \theta$ domain from 20 to $70^{\circ}$. The experimental powder patterns were analyzed using the Rietveld procedure provided in the Jana 2006 program $^{30}$. Refined unit cell and atomic parameters for the doped and undoped materials did not differ within the standard deviation limits. Raman spectra were recorded on a LabRAM Aramis IR ${ }^{2}$ Horiba JobinYvon spectrometer equipped with a He/Ne laser $(\lambda=633 \mathrm{~nm}, 17 \mathrm{~mW}$ on sample $)$ and an objective $\times 50$ long wide distance. Nitrogen adsorption/desorption isotherms were determined at $77 \mathrm{~K}$ by means of a Micromeritics ASAP 2020 apparatus after outgassing overnight at $200{ }^{\circ} \mathrm{C}$ under vacuum $\left(10^{-5}\right.$ Torr $)$. The specific surface area $\left(\mathrm{S}_{\mathrm{BET}}\right)$ was calculated using the BET equation ${ }^{31}$ and taking $0.162 \mathrm{~nm}^{2}$ as the crosssectional area of one $\mathrm{N}_{2}$ molecule.

The surface composition of the fibers was analyzed by X-ray photoelectron spectroscopy (XPS) on an ESCALAB 250 (ThermoElectron) instrument. The X-ray excitation was provided by a monochromatic $\mathrm{Al} \mathrm{K} \alpha(1486.6 \mathrm{eV})$ source. For the high resolution spectra, a constant analyzer energy mode was used for the electron detection ( $20 \mathrm{eV}$ pass energy). The detection of the emitted photoelectrons was performed perpendicular to the surface sample, and the analyzed surface was of diameter $400 \mu \mathrm{m}$. Data analysis was performed using the Avantage program, the background signal being removed using the Shirley method ${ }^{32}$. The surface atomic concentrations were determined from photoelectron peaks areas using the atomic sensitivity factors reported by Scofield $^{33}$. Binding energies $(\mathrm{BE})$ of all core levels are referred to the $\mathrm{C}-\mathrm{C}$ bond of $\mathrm{C} 1 \mathrm{~s}$ at 284.8 $\mathrm{eV}$.

Thermogravimetric analysis performed in air up to $1000^{\circ} \mathrm{C}$ at $10{ }^{\circ} \mathrm{C} \mathrm{min}^{-1}$ using a Netzsch TG 439 was used to determine characteristic weight loss profiles composite $\mathrm{SnO}_{2} / \mathrm{PVP}$ electrospun fibers. 
Electronic conductivity of $\mathrm{SnO}_{2}$ based fibers was determined at room temperature from resistance measurements carried out using an in-house conductivity cell equipped with four gold electrodes and using conventional Van Der Pauw calculations ${ }^{34}$. Samples were analyzed as pellets prepared by pressing at 5 tons for $10 \mathrm{~min}$.

The electrochemical analyses were carried out in a three-electrode cell equipped with a thermostat comprising a gold rotating disk electrode (RDE) of area $0.03 \mathrm{~cm}^{2}$ (working electrode), a saturated calomel electrode (SCE, reference electrode) and a platinum wire (counter electrode), and a Bio-Logic SP-150 potentiostat. To assess the stability to electrochemical corrosion, an accelerated stress test was performed by holding the working electrode potential at $1.4 \mathrm{~V}$ vs RHE for 2 hours in $0.5 \mathrm{M} \mathrm{H}_{2} \mathrm{SO}_{4}$ at $80{ }^{\circ} \mathrm{C}$. An ink was first prepared by dispersing (ultrasonication, 30 mins) $20 \mathrm{mg}$ of the support material $\left(5 \%\right.$ at $\mathrm{Nb}-\mathrm{SnO}_{2}$ loose-tubes or Vulcan XC-72, from Cabot) in $1 \mathrm{~mL}$ of ethanol (Aldrich) and $200 \mu \mathrm{L}$ of 5 wt. $\% \mathrm{Nafion}^{\circledR}$ dispersion in alcohols (Aldrich). $3 \mu \mathrm{L}$ of the inks were then deposited onto the RDE surface with a micropipette. In the case of the noncatalysed support, the ink composition was $5 \mathrm{mg}$ of the support material, $10 \mu \mathrm{l}$ of ultrapure water, $200 \mu 1$ of ethanol and $10 \mu l$ of Nafion dispersion.

Preparation of $\mathbf{P t} / \mathrm{SnO}_{2} 70 \mathrm{mg}$ of hexachloroplatinic acid $\left(\mathrm{H}_{2} \mathrm{PtCl}_{6} 6 \mathrm{H}_{2} \mathrm{O}, 99.9 \%\right.$ Alfa Aesar) were dissolved in $50 \mathrm{~mL}$ of ethylene glycol (99.5\%, Fluka) and brought to $\mathrm{pH} 11$ by addition of $\mathrm{NaOH}\left(98 \%\right.$, Sigma Aldrich). The resulting solution was heated at $130{ }^{\circ} \mathrm{C}$ for 6 minutes in reflux conditions and under a $\mathrm{N}_{2}$ atmosphere in a microwave reactor (MiniFlow 200SS Sairem) to obtain Pt nanoparticles. A suspension containing $55 \mathrm{mg}$ in of the $\mathrm{Nb}^{-\mathrm{SnO}_{2}}$ fibers in $5 \mathrm{~mL}$ ethylene glycol was added to the Pt nanoparticle solution. The $\mathrm{pH}$ was adjusted to $\mathrm{pH} 2$ by addition of $\mathrm{H}_{2} \mathrm{SO}_{4}$ (95-98 \%, Aldrich) and the suspension was stirred for $24 \mathrm{~h}$ to allow adsorption of Pt nanoparticles 
onto the support surface. The product was recovered by centrifugation (4000 rpm, 20 minutes) washed 5 times with water and dried in an oven at $80{ }^{\circ} \mathrm{C}$ for $24 \mathrm{~h}$.

Characterization of $\mathbf{P t} / \mathrm{SnO}_{2}$ based materials The Pt nanoparticles deposited on the alternative supports were characterized by TEM (JEOL 1200 EXII at $120 \mathrm{kV}$ ) of microtomed sections (see above). Electrochemical analyses were carried out using a three-electrode cell with a glassy carbon $\left(0.196 \mathrm{~cm}^{2}\right) \mathrm{RDE}$, an SCE and a Pt wire and a Pine bipotentiostat model AFCBP1. All the potential values are referred to a reversible hydrogen electrode (RHE). The electrochemically active surface area (ECSA) was determined at room temperature on materials deposited on the glassy carbon electrodes prepared with the following procedure. $5 \mathrm{mg}$ of $\mathrm{Pt} / \mathrm{SnO}_{2}$ were dispersed in $200 \mu \mathrm{L}$ of ethanol (Aldrich), $20 \mu \mathrm{L}$ of water and $10 \mu \mathrm{L}$ of $5 \% \mathrm{wt}$ Nafion ${ }^{\circledR}$ dispersion (ultrasound, 30 minutes). These inks were then deposited onto the RDE surface with a micropipette to give a final Pt loading of $116 \mu \mathrm{g} \cdot \mathrm{cm}^{-2}$ (geometric area). Before each measurements, the electrolyte was purged with $\mathrm{N}_{2}$ for $15 \mathrm{~min}$, and each electrode was cycled multiple times in $\mathrm{N}_{2}$ purged $0.1 \mathrm{M} \mathrm{HClO}_{4}$, sweeping in the potential range of 0.05 to $1.2 \mathrm{~V}$ vs RHE at a scan rate of $50 \mathrm{mVs}^{-1}$ to clean the Pt surface. ECSA was calculated by integrating the charge associated with $\mathrm{H}$ adsorption/desorption on the $\mathrm{Pt}$ surface, assuming a hydrogen desorption charge of $210 \mu \mathrm{C} \mathrm{cm}^{-2}$ for the electroactive Pt surface ${ }^{35}$ (after subtracting the baseline current of the double layer region due to the capacitive current of the charging/discharging of the electrical double layer). ECSA was calculated using the relation:

$$
\operatorname{ECSA}\left(\mathrm{cm}^{2} \mathrm{~g}^{-1}\right)=\mathrm{Q}(\mu \mathrm{C}) / \mathrm{Q}\left(\mu \mathrm{C} \mathrm{cm}{ }^{-2}\right) \mathrm{m}_{\mathrm{Pt}}(\mathrm{g})
$$

And the average value then calculated from both the hydrogen adsorption and desorption peaks. The highest ECSA value was calculated for cycle 12 and thus this was taken as the value quoted in this study.

\section{RESULTS AND DISCUSSION}

Previous investigations of $\mathrm{SnO}_{2}$ hollow fibers prepared by conventional electrospinning ${ }^{23}$ attributed their formation to the combination of the Kirkendall effect ${ }^{36}$ (diffusion of $\mathrm{SnCl}_{2}$ to the fiber surface due to a concentration gradient) with gas release during the decomposition of the 
carrier polymer (polyvinylpyrrolidone, PVP) driving the $\mathrm{SnO}_{2}$ nanoparticles to the surface ${ }^{25}$. The gas release was considered the dominant mechanism as tube formation was dependent on heating rate and PVP content. Below a certain threshold (PVP: $\mathrm{SnCl}_{2} .2 \mathrm{H}_{2} \mathrm{O}$ weight ratio of 1.33 ) only dense fibers were formed ${ }^{23,37}$. In contrast, in the study the loose-tube morphology was observed for $5 \%$ at $\mathrm{Nb} \mathrm{SnO}_{2}$ regardless of $\mathrm{SnCl}_{2}$ concentration (Figures 1a and 2) (3-15\% $\%_{\mathrm{w} / \mathrm{v}} \mathrm{SnCl}_{2}, \mathrm{PVP}: \mathrm{SnCl}_{2}$ weight ratio of $0.6-3)$ and heating rates $\left(1-10{ }^{\circ} \mathrm{C} / \mathrm{min}\right.$, see Figure 3). Even at very low $\mathrm{SnCl}_{2}$ concentration ( $3 \%_{\mathrm{w} / \mathrm{v}}, \mathrm{PVP}: \mathrm{SnCl}_{2}$ weight ratio of 3$)$, we observed broken, hollow structures reminiscent of hollow fibers without sufficient structural integrity to maintain a fibrillar morphology. As the $\mathrm{SnCl}_{2}$ concentration was increased, the tube diameter increased (from $300 \mathrm{~nm}$ to $2 \mu \mathrm{m}$ ) as well as the composing grain size (from 30 to $45 \mathrm{~nm}$ ), with the particles of the inner fiber observed to be smaller than those in the tube shell.

Notably, in the absence of niobium and under the same conditions, solid fibers were obtained, and a loose-tube structure is then observed only above a certain threshold of the particle size and fiber diameter (Figure 1b). For a given PVP concentration $\left(9 \% \%_{\mathrm{w} / \mathrm{v}}\right)$ when the inorganic precursor concentration reached $15 \%$ w/v $\left(\mathrm{PVP}: \mathrm{SnCl}_{2}\right.$ weight ratio of 0.3$)$, the size of the particles forming external tubes exceeded $30 \mathrm{~nm}$ and the fiber-in-tube morphology became dominant. Below this threshold, only dense fibers were obtained regardless of heating rate.

Varying the $\mathrm{Nb}$ doping level in $\mathrm{SnO}_{2}$ electrospun materials at a fixed $\mathrm{SnCl}_{2}$ concentration $\left(8.5 \% \%_{\mathrm{w} / \mathrm{v}}\right)$ confirmed this effect (Figure 4$)$. When the amount of niobium was increased, tubular morphology was favored, even when the constituent particle size was below $30 \mathrm{~nm}$, the threshold for tube formation in undoped $\mathrm{SnO}_{2}$. This indicates that the formation mechanism in the presence of $\mathrm{Nb}$ is not dependent on particle size or gas expansion (PVP content or heating rate) as for 
undoped $\mathrm{SnO}_{2}$, but rather related to the diffusion of tin species within the fibers during oxide formation.

To provide additional evidence to support this hypothesis, cross-sections of fibers prepared with and without niobium were treated at $300^{\circ} \mathrm{C}$ (when the fibers still contain the carrier polymer, PVP, as shown by the thermogravimetric analysis of Figure 5a) and were observed in TEM. A dispersion of $\mathrm{SnO}_{2}$ particles within the polymer fibers was observed in both types of materials (Figure $5 \mathrm{~b}$ and c). In undoped $\mathrm{SnO}_{2} / \mathrm{PVP}$ fibers, the particles were homogeneous in size (2-4 nm) and dispersed evenly within the fiber, corroborating a mechanism whereby tube formation is predominantly influenced by the degradation of PVP during calcination, the released gases pushing the $\mathrm{SnO}_{2}$ particles towards the exterior and forming the tube.

In contrast, $\mathrm{Nb}$-doped $\mathrm{SnO}_{2} / \mathrm{PVP}$ fibers clearly comprise an agglomeration of larger particles on the surface of the fiber and smaller particles $(1-2 \mathrm{~nm})$ clustered towards the inside, with a clear distinction in terms of particle size and quantity between the periphery and the center of the fibers. As it is known that the addition of niobium decreases the size of $\mathrm{SnO}_{2}$ crystallites ${ }^{27}$, ${ }^{29}$, it is likely that the inhibition of particle growth results in greater concentration and lifetime of precursor salt $\left(\mathrm{SnCl}_{2}\right)$ within the fibers, allowing for a greater rate of diffusion towards the fiber surface where contact with atmosphere facilitates $\mathrm{SnO}_{2}$ formation. This indicates that, here, the dominant mechanism is the Kirkendall effect (Scheme 1), where a concentration gradient results in diffusion of precursor towards the skin and away from the center of the fibers, resulting in particle formation closer to the fiber surface. After removal of the polymer, particles below the threshold of $30 \mathrm{~nm}$ in size collapse to the center of the fiber whereas the larger particles remain self-supported on the exterior, forming the shell of the loose-tube fibers. Thinner fibers $(<500 \mathrm{~nm}$ diameter) do not possess sufficient girth to form the hollow structures reported in the literature ${ }^{23}$, 
and thus remain as solid fibers. The results of thermogravimetric analysis and microscopic analysis also show that $\mathrm{SnO}_{2}$ is formed at temperatures well below $500{ }^{\circ} \mathrm{C}$, which may be assisted by the presence of organic decomposition products from the PVP carrier polymer. A previous study has shown that tin oxide can be formed in the temperature range of $200-400{ }^{\circ} \mathrm{C}^{38}$, well below the final decomposition temperature of PVP, but above its glass transition temperature.

Closer observation by high resolution EDS indicates that the $\mathrm{Nb}$ content is unevenly distributed between the inner fibers and the outer tubes. For a nominally $5 \%$ at doped sample, the average niobium content is $2.5 \pm 0.6 \%$ at for the inner fibers, while for the external tubes it is only $0.6 \pm 0.4 \%$ at. This result strongly supports our hypothesis regarding the difference in grain size for the two 1D structures relative to the proposed mechanism of their formation: the inner, solid fibers are composed of small particles with higher content of the growth-inhibiting niobium, while the outer, hollow fibers consist of particles of greater size and lower $\mathrm{Nb}$ content.

The influence of ramp rate during thermal treatment and of the niobium content on fiber vs. tube morphology was also investigated. If, for undoped $\mathrm{SnO}_{2}$, fast heating rates are required to facilitate hollow fiber formation ${ }^{23}$, for the $\mathrm{Nb}$ dopant-driven, Kirkendall effect-dominated mechanism, the tubular morphology is obtained regardless of heating rate. Interestingly, in $\mathrm{Nb}-$ doped materials, slow heating resulted in more compact tubes with a larger inner fiber, whereas high heating rate resulted in the addition of the effect of gas expansion to the Kirkendall effect, creating loose-tube fibers of larger diameters with smaller inner fibers (Figure 3). With regard to the effect of $\mathrm{Nb}$ content, solid fibers were formed at very low $\mathrm{Nb}$ doping level ( $0.5 \%$ at $)$, but at higher dopant concentration firstly an exterior shell, and finally at $5 \% \mathrm{at} \mathrm{Nb}$ the loose-tube morphology was obtained. Increasing the doping level further to $10 \%$ at $\mathrm{Nb}$ did not remove the inner fiber to give a true hollow fiber morphology, however it did increase the homogeneity and 
cylindrical shaping of the fibers. The doping level does not affect the size of the particles forming the sheath, but rather the size of the particles forming the inner fibers, which decreases with increasing doping level up to $5 \% \mathrm{at} \mathrm{Nb}$ (Figure 6). This results in a greater size difference between external and inner particle size at high doping level, driving the formation of the fiber-in-tube morphology.

The change in morphology from solid to loose-tube fibers impacts the specific surface area. Nitrogen adsorption-desorption measurements confirmed the increased porosity and specific surface area as the morphology evolves: for example, for samples prepared with $9 \%{ }_{\mathrm{w} / \mathrm{v}} \mathrm{SnCl}_{2}$ the surface area of $\mathrm{Nb}$-doped $\mathrm{SnO}_{2}$ hollow structures is $50 \mathrm{~m}^{2} \mathrm{~g}^{-1}$, notably higher than that $\left(20 \mathrm{~m}^{2} \mathrm{~g}^{-1}\right)$ of undoped $\mathrm{SnO}_{2}$ solid fibers.

No significant crystallographic variation was observed between undoped and $\mathrm{Nb}$-doped $\mathrm{SnO}_{2}$ materials. XRD (Figure 7) showed both sample types to have the same crystal structure, with XRD line position and intensity giving lattice parameters in good agreement with standard data (JCPDS 41-1445) of the tetragonal $\mathrm{P}_{2} / \mathrm{mnm}$ cassiterite structure. This is not unexpected, given the comparable ionic radii $\left(0.69,0.64,0.68\right.$ and $0.72 \AA$ for $\mathrm{Sn}^{4+}, \mathrm{Nb}^{5+}, \mathrm{Nb}^{4+}$ and $\mathrm{Nb}^{3+}$ respectively) that enable partial replacement of tin by niobium on the regular lattice site without significant cell volume variations. Similarities in $\mathrm{Nb}$ and $\mathrm{Sn}$ outer shell electronic configurations make possible substitutional doping as was evidenced recently for iron-doped $\mathrm{SnO}_{2}{ }^{39}$. Finally, no extra diffraction peaks that would indicate the presence of a segregated niobium oxide phase were detected. The cassiterite structure was further confirmed by Raman spectroscopy, where lines were observed at characteristic positions ${ }^{40}$ (See S.I.).

Furthermore, there was a significant increase of a factor 20 in the electrical conductivity upon $\mathrm{Nb}$-doping (from $1.110^{-3}$ to $2.1010^{-2} \mathrm{~S} \mathrm{~cm}^{-1}$ at $\mathrm{RT}$ for $5 \% \mathrm{at} \mathrm{Nb}$ ) which supports our previous 
observation. The conductivity values for the various doping levels are given in Table 1 . The highest conductivity was obtained for the sample doped with $5 \% \mathrm{at} \mathrm{Nb}$, with a decrease in conductivity upon further doping which indicates an optimum doping level at around this value. Such phenomenon has been previously observed in semiconducting oxides, and is attributed to defect interactions and changes in the electronic structure ${ }^{13,41}$.

X-ray photoelectron spectroscopy was used to analyze the surface composition, and high resolution spectra for $\mathrm{Sn}$ are shown in Figure 8a. For both $\mathrm{Nb}$-doped and undoped samples, the respective peak positions of $\mathrm{Sn} 3 \mathrm{~d}_{5 / 2}$ at $486.6 \mathrm{eV}$ and $486.8 \mathrm{eV}$ can be attributed to the highest oxidation state, $\mathrm{Sn}^{4+}$. Nevertheless, it is agreed that the peak position is not sufficient to distinguish $\mathrm{Sn}^{4+}$ from $\mathrm{Sn}^{2+}$ species ${ }^{42}$. Some indication of the oxidation state can also be derived from the stoichiometric ratio $\mathrm{Sn} / \mathrm{O}$, utilising the $\mathrm{O} 1 \mathrm{~s}$ peak at $530.7 \mathrm{eV}$ attributed to the metal oxide and taking into account the semi-quantitative nature of XPS. In this regard, both undoped and Nb-doped materials show sub-stoichiometric ratios of 0.72 and 0.55 (considering the partial substitution of $\mathrm{Sn}$ by $\mathrm{Nb}$ ). In addition to the $3 \mathrm{~d}$ core level position, the value of the modified Auger parameter $\alpha$ ' $\left(\mathrm{BE}\right.$ Sn $3 \mathrm{~d}_{5 / 2}+\mathrm{KE}$ Sn MNN, with $\mathrm{BE}=$ binding energy of the emitted photoelectron and $\mathrm{KE}=$ kinetic energy of the Auger electron related to the MNN transition) can be a reliable indicator of the charge state of $\mathrm{Sn}^{43}$. Figure $8 \mathrm{~b}$ shows that the Auger peaks for undoped and doped tin oxide are very similar ( $\mathrm{KE}=432.7$ and 432.4 , respectively). Consequently, the $\alpha$ ' values calculated for $\mathrm{Sn}$ in $\mathrm{SnO}_{2}$ and $\mathrm{Nb}$ doped $\mathrm{SnO}_{2}$ samples were practically identical (respectively 919.3 and 919.2) indicating surfaces comprising non-stoichiometric $\mathrm{SnO}_{\mathrm{x}}(\mathrm{x}<2)^{44,45}$. It may be concluded that the material surface comprises oxygen deficient $\mathrm{SnO}_{2}$, and $\mathrm{Sn}^{2+}$ in addition to $\mathrm{Sn}^{4+}$. The $\mathrm{Nb} 3 \mathrm{~d}_{5 / 2}$ peak at $207.5 \mathrm{eV}$ (See S.I.) is in agreement with a +5 oxidation state, as would be expected in a mixed 
niobium/tin oxide, and consistent with the above observations by XRD and with the conductivity values that increase on niobium doping ${ }^{46}$.

Finally, and in the perspective of the possible utilization of electrospun $\mathrm{Nb}$-doped $\mathrm{SnO}_{2}$ as fuel cell electrocatalyst supports, their resistance to oxidative corrosion was evaluated by an accelerated stress test ${ }^{47}$ and compared to a conventional carbon support (Vulcan XC-72). Electrochemical degradation was estimated in terms of loss or modification of the support from the integrated corrosion current, Figure 9. The carbon material shows a much larger corrosion current ${ }^{48}$, reflecting its corrosion behavior i.e. the oxidation of carbon to $\mathrm{CO}_{2}{ }^{49}$, than that recorded on $\mathrm{SnO}_{2}$ electrospun materials. The integrated charges for $5 \%$ at $\mathrm{Nb}_{-} \mathrm{SnO}_{2}$ and Vulcan XC-72 were respectively 0.9 and $3.9 \mathrm{C} \mathrm{mg}^{-1}$. The tin oxide based material shows smaller corrosion charge and then higher electrochemical stability to high potential than carbon black.

The most conductive sample $\left(5 \%\right.$ at $\mathrm{Nb}$ doped $\left.\mathrm{SnO}_{2}\right)$ was used as a support for $\mathrm{Pt}$ nanoparticles prepared by a microwave-assisted polyol method. High resolution TEM micrographs of a microtomed section are shown in Fig. 10. The Pt particles (average diameter $2.5 \mathrm{~nm}$ ) are very well dispersed both on the outer surface and on the inner surface of the tubes (indicated by black arrows in Fig. 10 a). This shows that the internal pore space of the loose tube fibers is accessible to the nanocatalyst, which potentially increases the Pt loading possible on this type of support, while the good dispersion and small particle size favor high Pt electroactive area and are expected to enhance the triple phase boundary in PEMFC applications ${ }^{50}$. The diffraction pattern within Fig. $10 \mathrm{~b}$ shows the crystal nature of the sample and the presence of $\mathrm{SnO}_{2}$ cassiterite with the typical $d_{(110)}$ of $3.35 \AA$ (JCPDS 41-1445), and of Pt with the typical $d_{(111)}$ of $2.26 \AA$ (JCPDS 4-0802).

The electrochemical properties of the $\mathrm{Pt} / \mathrm{Nb}-\mathrm{SnO}_{2}$ supported electrocatalyst were investigated by cyclic voltammetry measurements in $0.1 \mathrm{M} \mathrm{HClO}_{4}$ at a scan rate of $50 \mathrm{mVs}^{-1}$. As 
depicted in Fig. 11, the bare $\mathrm{Nb}-\mathrm{SnO}_{2}$ support did not show any electrochemical activity, but when Pt is present (at $13 \%$ loading) typical hydrogen adsorption/desorption peaks ( $<0.3 \mathrm{~V}$ vs RHE) and Pt oxide formation $(>0.8 \mathrm{~V})$ and reduction $(0.6-1 \mathrm{~V})$ were observed. The electrochemical surface area (ECSA) calculated from the $\mathrm{H}$ adsorption/desorption peaks was $53 \mathrm{~m}^{2} \mathrm{~g}^{-1}$. As shown in Figure 12, electrochemical cycling of the $\mathrm{Pt} / \mathrm{Nb}-\mathrm{SnO}_{2}$ shows good electrochemical stability with a retention of $80 \%$ of the ECSA after 1000 cycles (from $53 \mathrm{~m}^{2} \mathrm{~g}^{-1}$ before to $42 \mathrm{~m}^{2} \mathrm{~g}^{-1}$ after cycling) compared to $47 \%$ for commercial carbon support (E-TEK) ${ }^{11}$. This also compares favorably to literature values on $\mathrm{Nb}$-doped $\mathrm{SnO}_{2}$ of differing morphologies such as nanoparticles evaluated under similar conditions which showed a value of around $70 \%$ retention of $\mathrm{ECSA}^{51}$, as well as studies on alternative supports such as $\mathrm{Nb}$-doped $\mathrm{TiO}_{2}$ particles or fibers ${ }^{52,53}$. Further studies of such oxide based PEMFC electrodes with different Pt loadings are in progress in order to assess their electrocatalytic activity and electrochemical stability towards oxygen reduction and provide further insight into their potential for use in PEM fuel cells.

\section{CONCLUSION}

A novel complex loose-tube morphology has been obtained for $(\mathrm{Nb})-\mathrm{SnO}_{2}$ by conventional, singleneedle electrospinning. The mechanism of formation has been elucidated allowing the precise control of the morphology and dimensions through heating rate, dopant and precursor concentrations. The presence of niobium significantly drives the morphology of electrospun $\mathrm{SnO}_{2}$, which, in combination with the use of electrospinning as a routine deposition technique, leads to new types of tailored architectures with properties of surface area, adsorption characteristics for $\mathrm{Pt}$, electronic conductivity and electrochemical stability to high potential that are hold great promise for PEMFC application. 


\section{ASSOCIATED CONTENT}

Supporting Information. Structural data, Raman and XPS spectra are provided as Supporting Information. This material is available free of charge via the Internet at http://pubs.acs.org.

\section{AUTHOR INFORMATION}

\section{Corresponding Author}

* Deborah J. Jones

Institut Charles Gerhardt, UMR CNRS 5253 Agrégats Interfaces et Matériaux pour l'Energie, Université Montpellier 2, 34095 Montpellier Cedex 5 (France)

deborah.jones@univ-montp2.fr.

\section{ACKNOWLEDGEMENTS}

The research leading to these results has received funding from the Future Emerging Technologies for Energy Applications (FET) programme, within the European Union's Seventh Framework Programme (FP7/2010-2013), Grant Agreement 256821, QuasiDry. It has also received funding from the European Research Council under ERC Grant Agreement 306682. IS acknowledges a fellowship during part of this work from the FP7 Initial Training Network SUSHGEN, Grant Agreement 238678. 


\section{FIGURES}
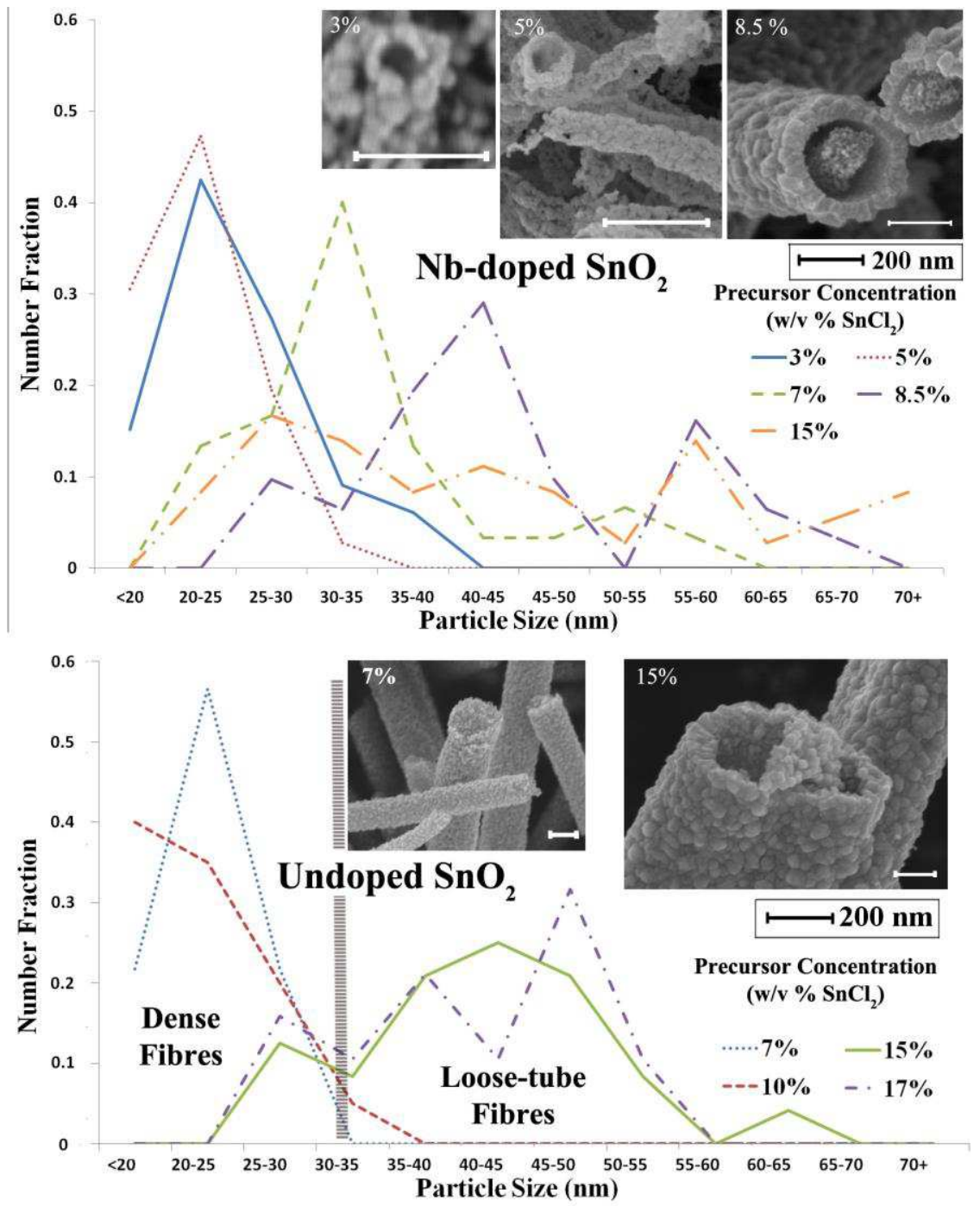

Figure 1. Grain size distribution and $\mathrm{SEM}$ images of $5 \%$ at $\mathrm{Nb}$ doped (a) and undoped (b) $\mathrm{SnO}_{2}$ electrospun materials as a function of the inorganic precursor content $\left(\%_{\mathrm{w} / \mathrm{v}}\right)$. 


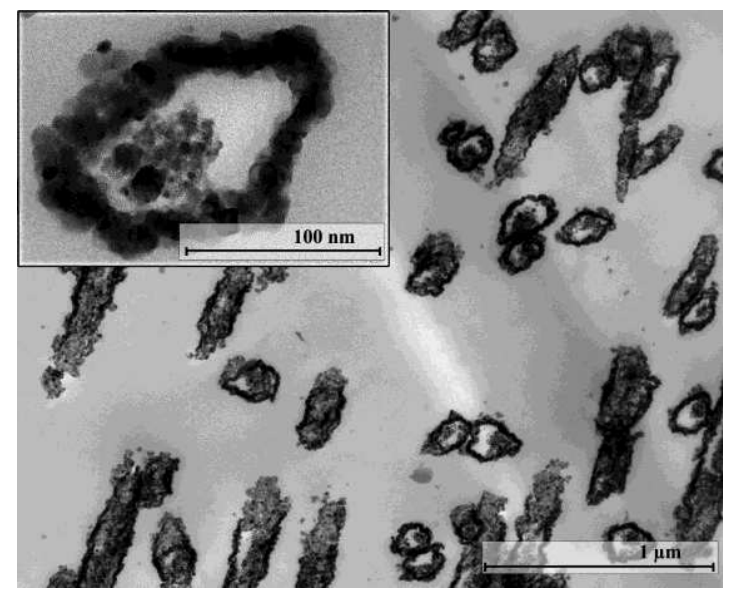

Figure 2. TEM micrographs of microtomed sections of $5 \%$ at $\mathrm{Nb}-\mathrm{SnO}_{2}$ loose-tubes obtained using $8.5 \%$ w/v of $\mathrm{SnCl}_{2}$; inset: close-up of the cross-section of a loose-tube fiber.
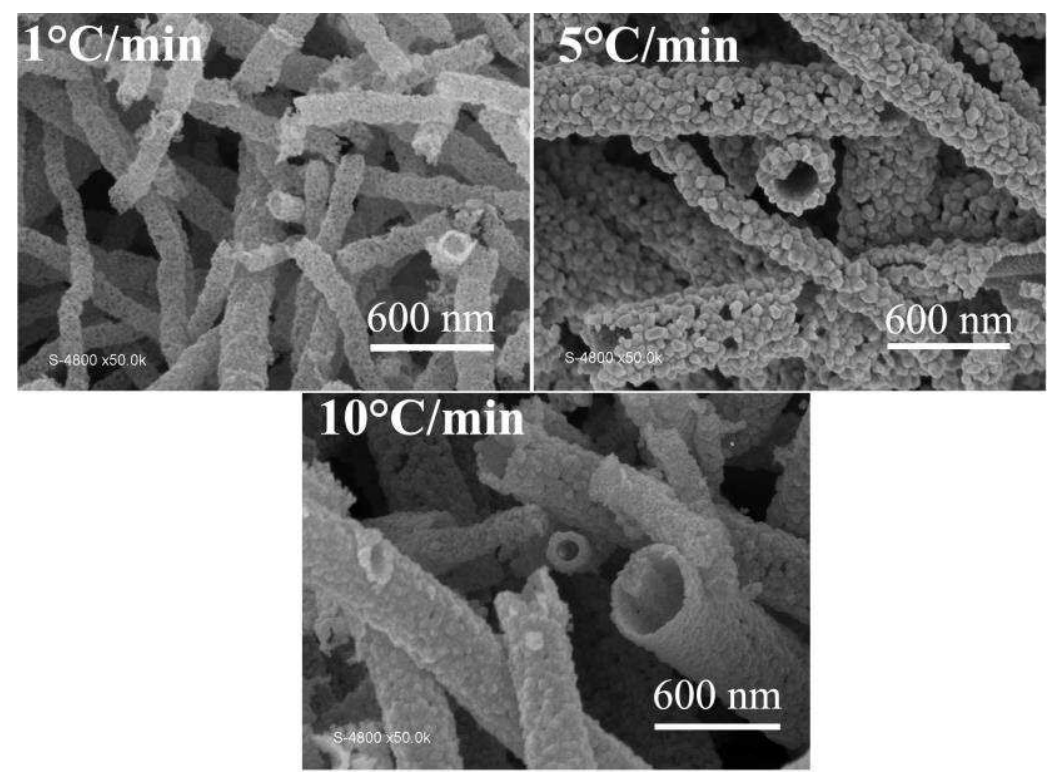

Figure 3. Loose-tubes of niobium-doped $\mathrm{SnO}_{2}\left(8.5 \% \%_{\mathrm{w} / \mathrm{v}} \mathrm{SnCl}_{2}\right.$ and $5 \%$ at $\left.\mathrm{Nb}\right)$ prepared using heating rates of 1,5 and $10{ }^{\circ} \mathrm{C} / \mathrm{min}$ during calcination. 


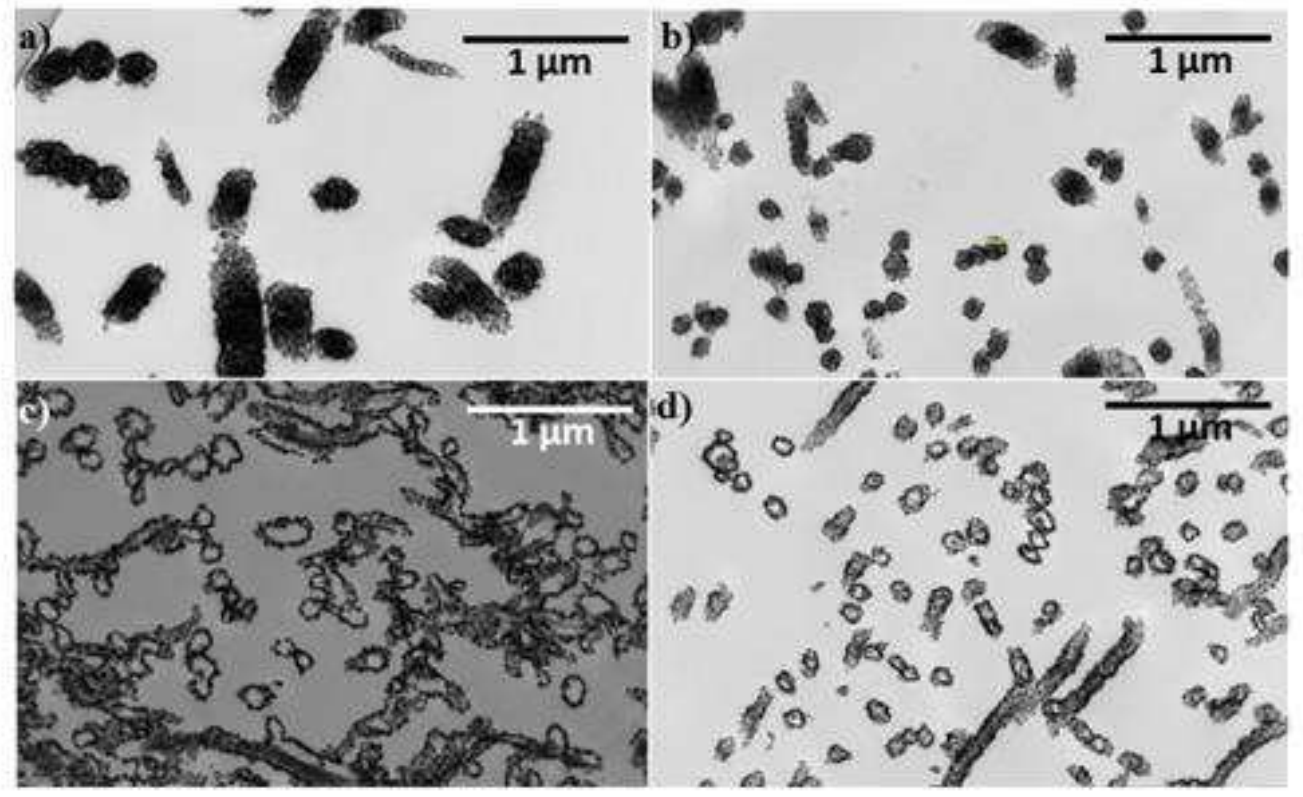

Figure 4. TEM micrographs of microtomed sections of $\mathrm{SnO}_{2}$ loose-tubes doped with 0.5 (a), 2 (b), 5 (c), and $10 \%{ }_{a t} \mathrm{Nb}(\mathrm{d})$ (all fibers obtained using $8.5 \% \%_{\mathrm{w} / \mathrm{v}}$ of $\mathrm{SnCl}_{2}$ ). 


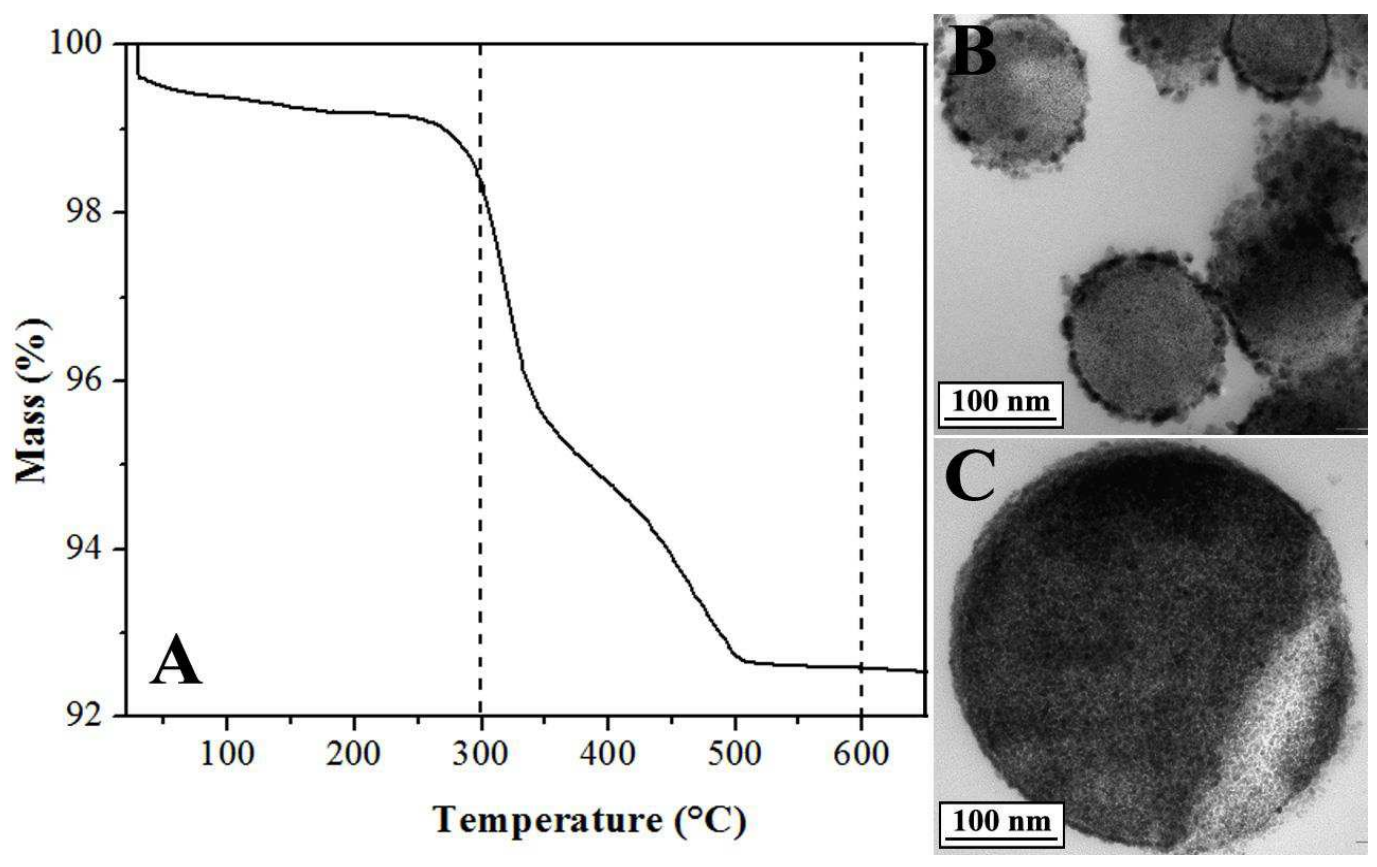

Figure 5. Thermogravimetric analysis of $\mathrm{SnCl}_{2} / \mathrm{PVP}$ with $5 \%$ at $\mathrm{Nb}$ precursor electrospun materials (a); TEM micrographs of microtomed sections of $5 \% \mathrm{at} \mathrm{Nb}_{-} \mathrm{SnO}_{2}\left(8.5 \% \mathrm{w} / \mathrm{v}\right.$ of $\left.\mathrm{SnCl}_{2}\right)$ (b) and undoped $\mathrm{SnO}_{2}$ fibers $\left(15 \% \%_{\mathrm{w} / \mathrm{v}}\right.$ of $\left.\mathrm{SnCl}_{2}\right)(\mathrm{c})$ thermally treated at $300{ }^{\circ} \mathrm{C}$ for 4 hours. 

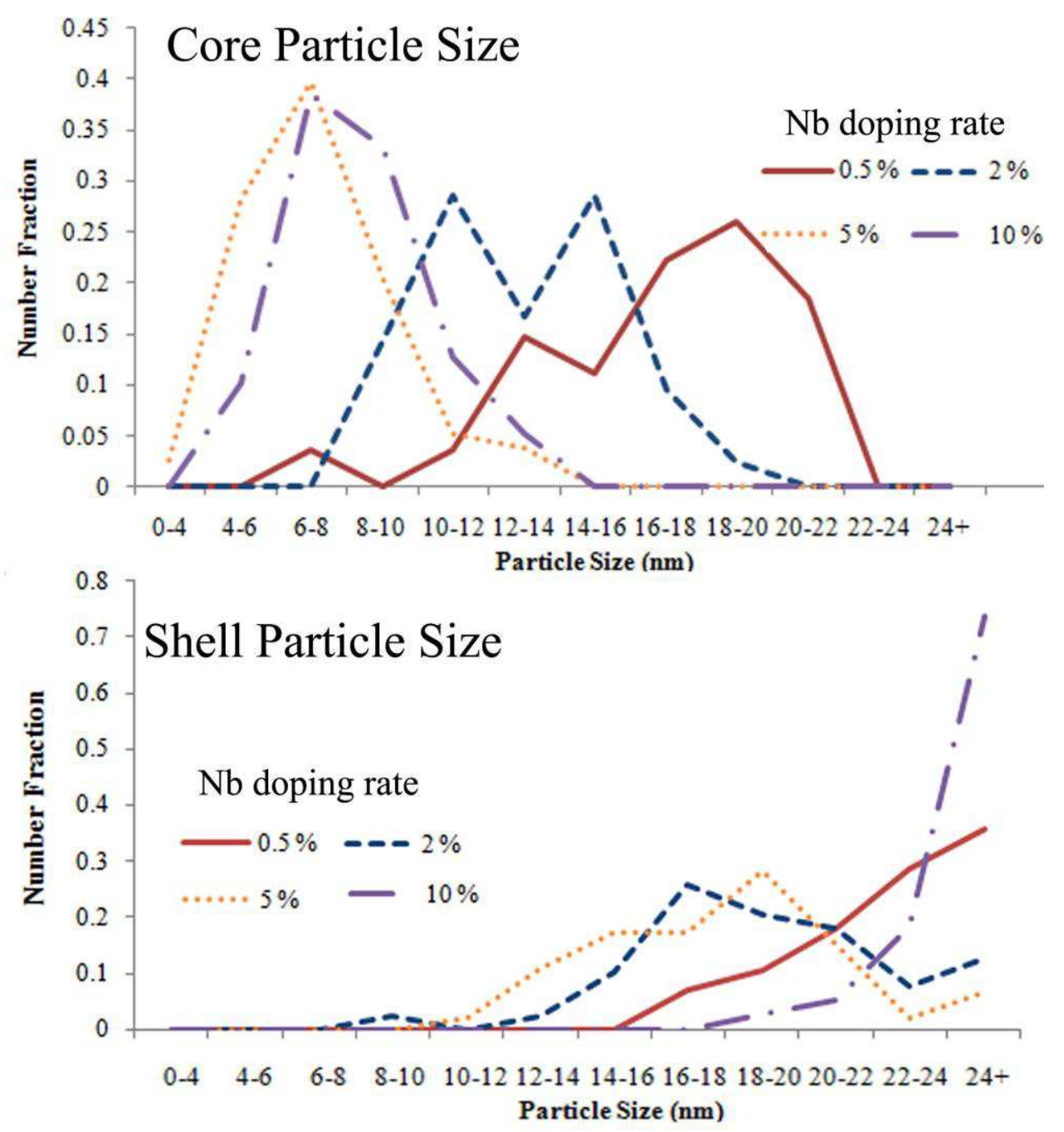

Figure 6. Comparison of the interior (core) and surface (shell) particle size for $\mathrm{SnO}_{2}$ loose-tube fibers doped with $0.5,2,5$, and $10 \%$ at $\mathrm{Nb}$ (all fibers obtained using $8.5 \% \mathrm{w} / \mathrm{v}$ of $\mathrm{SnCl}_{2}$ ). 


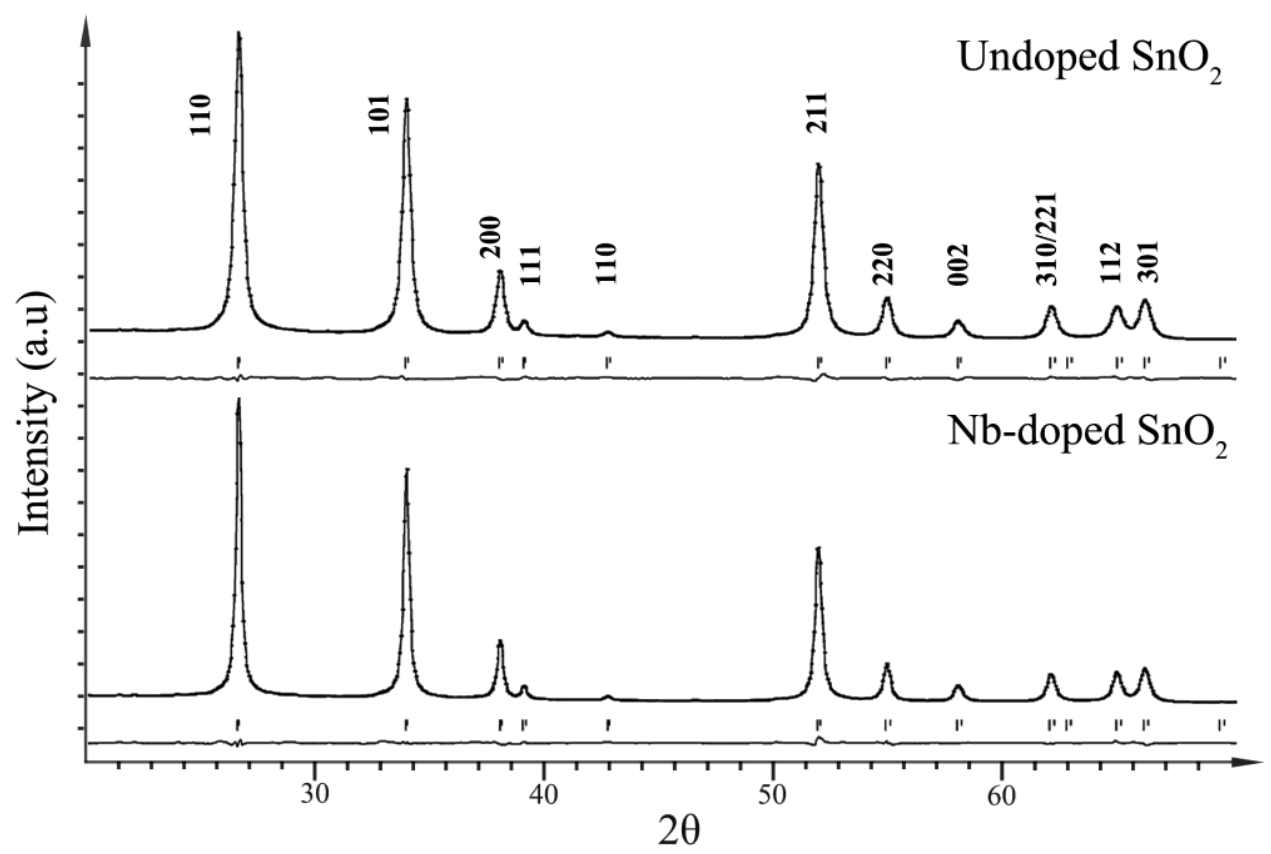

Figure 7. Experimentally observed (crosses) and calculated (solid line) X-ray diffraction $\left(\mathrm{Cu} \mathrm{K}_{\alpha}\right)$ intensity profiles for undoped and $5 \%$ at $\mathrm{Nb}$-doped $\mathrm{SnO}_{2}$ samples. The (observed-calculated) difference is plotted at the bottom of the diagram and positions of Bragg possible reflections are indicated with vertical markers. Structures were refined using the Rietveld method and refined structural parameters given in Supplementary Information. 

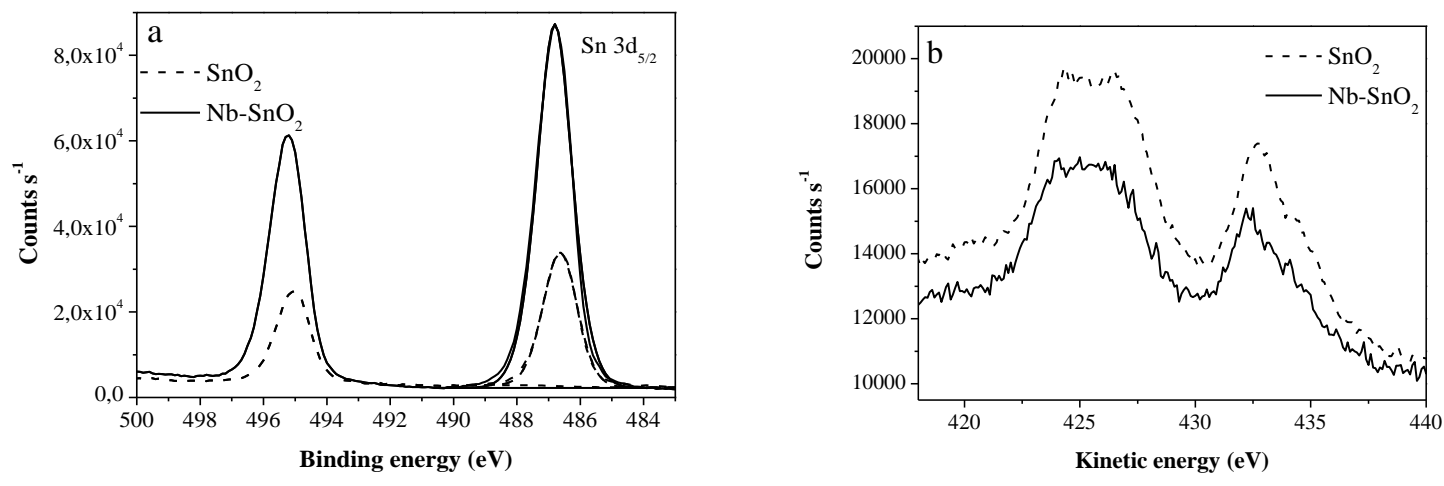

Figure 8. XPS high resolution (a) and Auger emission (b) spectra of the $\mathrm{Sn}$ region for $\mathrm{SnO}_{2}$ and 5 $\%$ at $\mathrm{Nb}-\mathrm{SnO}_{2}$ electrospun materials. 

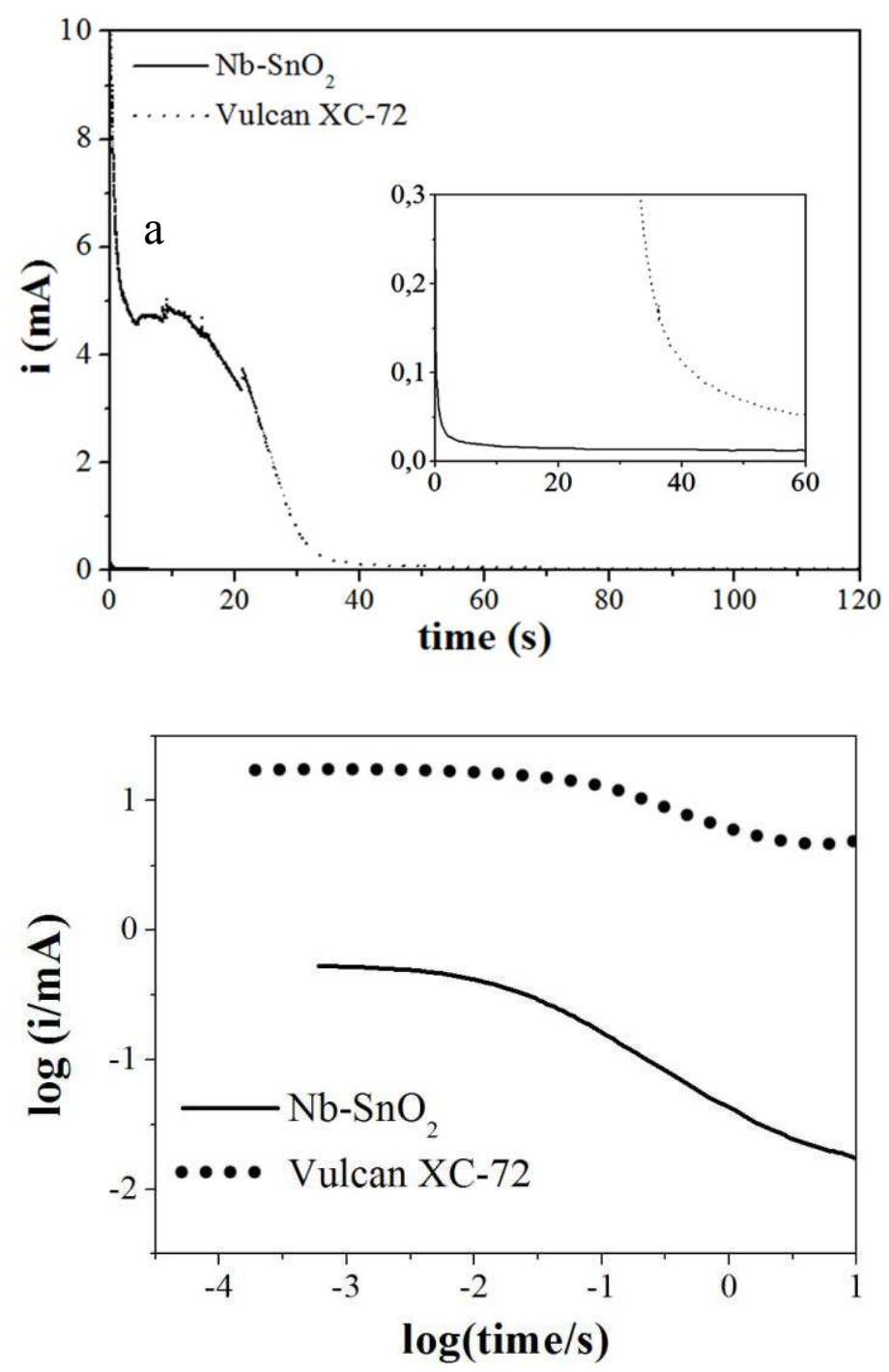

Figure 9. Oxidation/corrosion characteristics in linear (a) and logarithmic scales (b) for electrospun $5 \%$ at $\mathrm{Nb}-\mathrm{SnO}_{2}$ and Vulcan $\mathrm{XC}-72$ at $1.4 \mathrm{~V}$ vs RHE, $2 \mathrm{~h}$. 
(a)

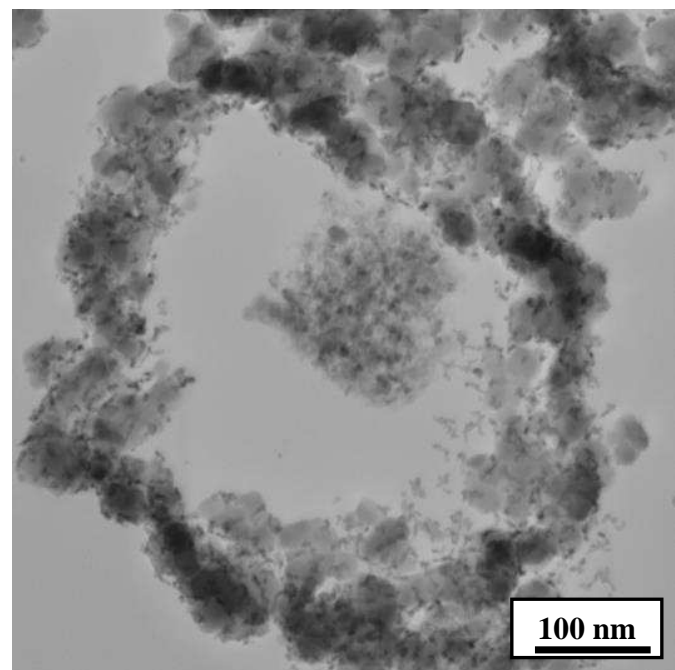

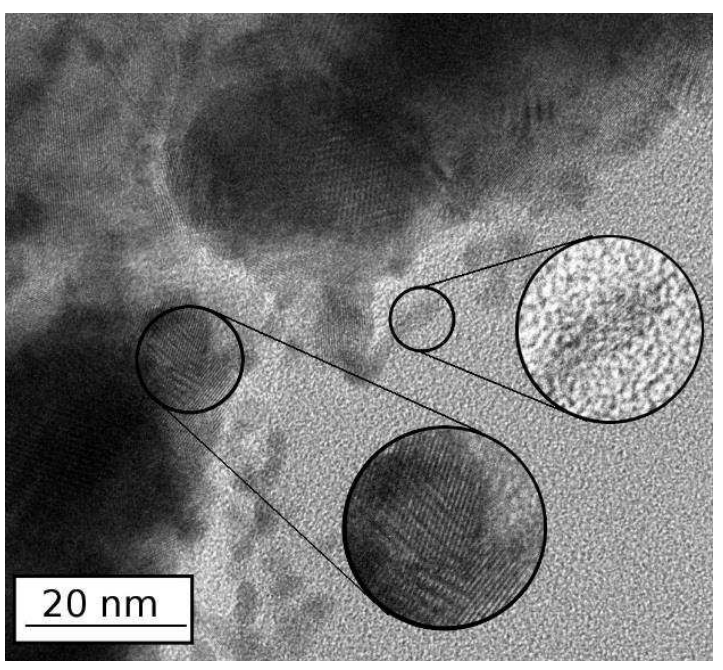

(b)

Figure 10. STEM (a) and HRTEM (b) micrographs (with magnification of $\mathrm{SnO}_{2}$ and $\mathrm{Pt}$ nanoparticles areas) of microtomed sections of Pt loaded $5 \%$ at $\mathrm{Nb}-\mathrm{SnO}_{2}$ loose-tubes.

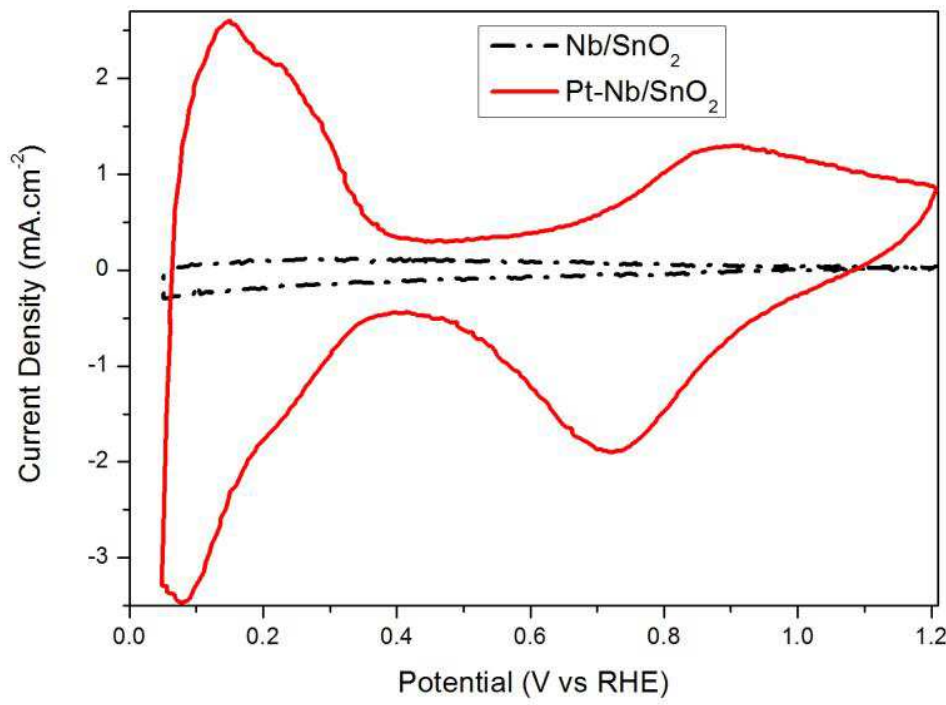

Figure 11. Cyclic voltammogramm of bare and $13 \%$ wt $\mathrm{Pt}$ loaded $\mathrm{Nb}-\mathrm{SnO}_{2}$ loose-tube fibers. 


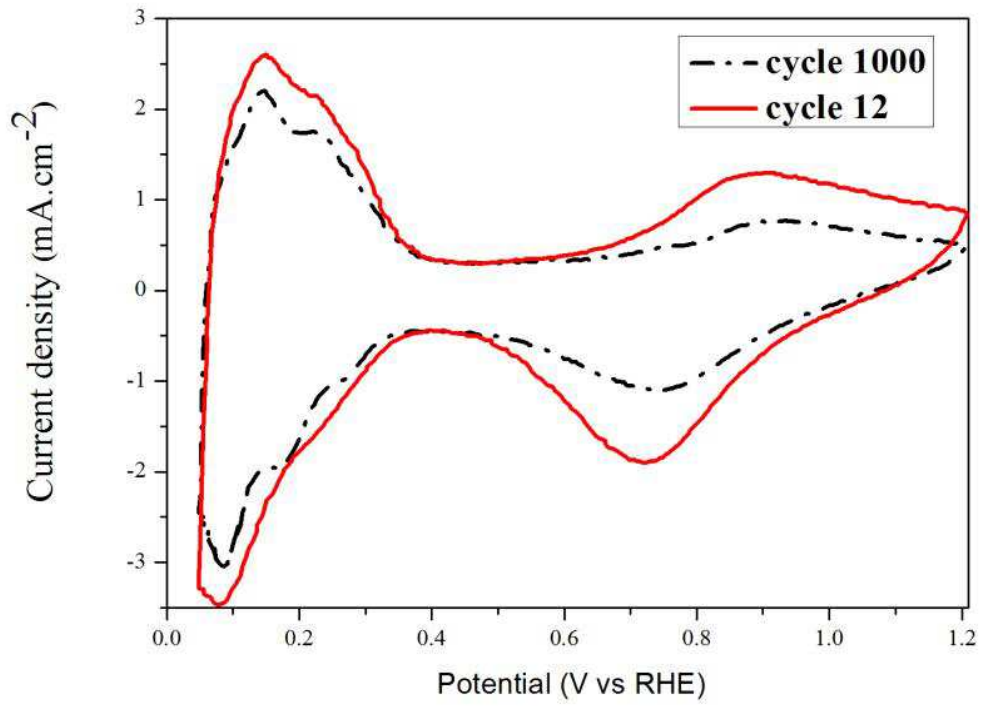

Figure 12. Electrochemical cycling of $\mathrm{Pt} / \mathrm{Nb}-\mathrm{SnO}_{2}$ fibers with $13 \% \mathrm{wt}$ Pt loading.

\section{SCHEMES}

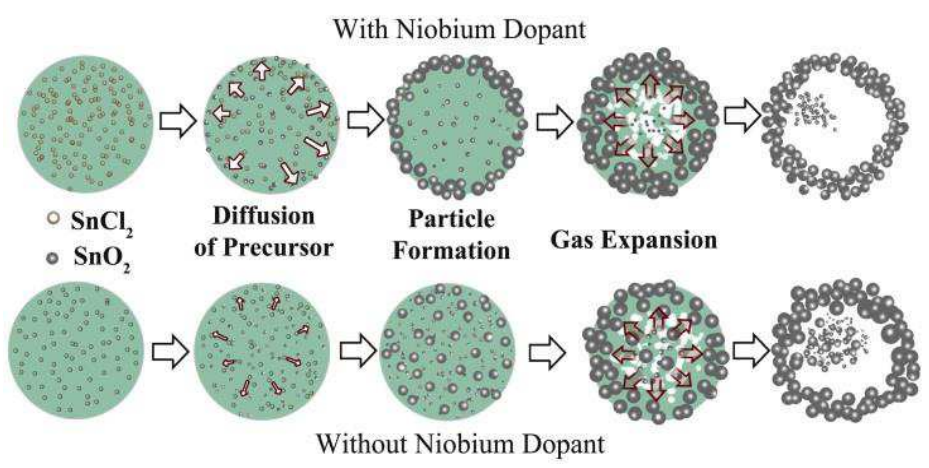

Scheme 1. Proposed mechanism of formation of fiber-in-tube structures for undoped and Nb-doped $\mathrm{SnO}_{2}$ electrospun materials. 


\section{TABLES}

Table 1. Electrical conductivity values for $\mathrm{Nb}-\mathrm{SnO}_{2}$ fibers.

\begin{tabular}{cc}
\hline Nb (\%at) & Electrical conductivity $\left(\mathbf{S ~ c m}^{-1}\right)$ \\
\hline 0 & 0,0011 \\
0.5 & 0,0028 \\
2 & 0,0086 \\
5 & 0,0210 \\
8 & 0,0078 \\
\hline
\end{tabular}

\section{REFERENCES}

(1) Wang, Z.; Zhou, L.; Lou, X. W. Metal Oxide Hollow Nanostructures for Lithiumion Batteries. Adv. Mater. 2012, 24, 1903-1911.

(2) Park, M.-S.; Wang, G.-X.; Kang, Y.-M.; Wexler, D.; Dou, S.-X.; Liu, H.-K. Preparation and Electrochemical Properties of $\mathrm{SnO}_{2}$ Nanowires for Application in Lithium-Ion Batteries. Angew. Chem. Int. Ed. 2007, 46, 750-753.

(3) Kumar, E. N.; Jose, R.; Archana, P. S.; Vijila, C.; Yusoff, M. M.; Ramakrishna, S. High performance dye-sensitized solar cells with record open circuit voltage using tin oxide nanoflowers developed by electrospinning. Energy Environ. Sci. 2012, 5, 5401-5407.

(4) Dou, X.; Sabba, D.; Mathews, N.; Wong, L. H.; Lam, Y. M.; Mhaisalkar, S. Hydrothermal Synthesis of High Electron Mobility Zn-doped $\mathrm{SnO}_{2}$ Nanoflowers as Photoanode Material for Efficient Dye-Sensitized Solar Cells. Chem. Mater. 2011, 23, 3938-3945.

(5) Kim, I.-D.; Rothschild, A. Nanostructured metal oxide gas sensors prepared by electrospinning. Polym. Adv. Tech. 2010, 22, 318-325.

(6) Batzill, M.; Diebold, U. The surface and materials science of tin oxide. Prog. Surf. Sci. 2005, 79, 47-154.

(7) Antolini, E.; Gonzalez, E. R. Ceramic materials as supports for low-temperature fuel cell catalysts. Solid State Ionics 2009, 180, 746-763.

(8) Shao, Y. Y.; Liu, J.; Wang, Y.; Lin, Y. H. Novel catalyst support materials for PEM fuel cells: current status and future prospects. J. Mater. Chem. 2009, 19, 46-59. 
(9) Shao, Y.; Yin, G.; Gao, Y. Understanding and approaches for the durability issues of Pt-based catalysts for PEM fuel cell. J. Power Sources 2007, 171, 558-566.

(10) Siracusano, S.; Baglio, V.; D’Urso, C.; Antonucci, V.; Aricò, A. S. Preparation and characterization of titanium suboxides as conductive supports of $\mathrm{IrO}_{2}$ electrocatalysts for application in SPE electrolysers. Electrochim. Acta 2009, 54, 6292-6299.

(11) Chevallier, L.; Bauer, A.; Cavaliere, S.; Hui, R.; Rozière, J.; Jones, D. J. Mesoporous Nanostructured Nb-Doped Titanium Dioxide Microsphere Catalyst Supports for PEM Fuel Cell Electrodes. ACS Appl. Mater. Interf. 2012, 4, 1752-1759.

(12) Ignaszak, A.; Teo, C.; Ye, S.; Gyenge, E. Pt-SnO $2-\mathrm{Pd} / \mathrm{C}$ Electrocatalyst with Enhanced Activity and Durability for the Oxygen Reduction Reaction at Low Pt Loading: The Effect of Carbon Support Type and Activation. J. Phys. Chem. C 2010, 114, 16488-16504.

(13) Takasaki, F.; Matsuie, S.; Takabatake, Y.; Noda, Z.; Hayashi, A.; Shiratori, Y.; Ito, K.; Sasaki, K. Carbon-Free Pt Electrocatalysts Supported on $\mathrm{SnO}_{2}$ for Polymer Electrolyte Fuel Cells: Electrocatalytic Activity and Durability. J. Electrochem. Soc. 2011, 158 B1270-B1275.

(14) Xia, Y.; Yang, P.; Sun, Y.; Wu, Y.; Mayers, B.; Gates, B.; Yin, Y.; Kim, F.; Yan, H. One-Dimensional Nanostructures: Synthesis, Characterization, and Applications. Adv. Mater. 2003, 15, 353-389.

(15) Wen, Z.; Wang, Q.; Zhang, Q.; Li, J. In Situ Growth of Mesoporous $\mathrm{SnO}_{2}$ on Multiwalled Carbon Nanotubes: A Novel Composite with Porous-Tube Structure as Anode for Lithium Batteries. Adv. Funct. Mater. 2007, 17, 2772-2778.

(16) Wang, H. E.; Xi, L. J.; Ma, R. G.; Lu, Z. G.; Chung, C. Y.; Bello, I.; Zapien, J. A. Microwave-assisted hydrothermal synthesis of porous $\mathrm{SnO}_{2}$ nanotubes and their lithium ion storage properties. J. Solid State Chem. 2012, 190, 104-110.

(17) Bae, C.; Yoo, H.; Kim, S.; Lee, K.; Kim, J.; Sung, M. M.; Shin, H. TemplateDirected Synthesis of Oxide Nanotubes: Fabrication, Characterization, and Applications. Chem. Mater. 2008, 20, 756-767.

(18) Carney, C.; Akbar, S. Nano-Structured Ceramics by Gas-Phase Reaction. ECS Trans. 2006, 3, 107-113.

(19) Greiner, A.; Wendorff, J. H. Electrospinning: A Fascinating Method for the Preparation of Ultrathin Fibers. Angew. Chem. Int. Ed. 2007, 46, 5670-5703.

(20) Cavaliere, S.; Subianto, S.; Savych, I.; Jones, D. J.; Roziere, J. Electrospinning: designed architectures for energy conversion and storage devices. Energy Environ. Sci. 2011, 4, 4761-4785.

(21) Yuan, T.; Zhao, B.; Cai, R.; Zhou, Y.; Shao, Z. Electrospinning based fabrication and performance improvement of film electrodes for lithium-ion batteries composed of $\mathrm{TiO}_{2}$ hollow fibers. J. Mater. Chem. 2011, 21, 15041-15048.

(22) Cho, N. G.; Yang, D. J.; Jin, M.-J.; Kim, H.-G.; Tuller, H. L.; Kim, I.-D. Highly sensitive $\mathrm{SnO}_{2}$ hollow nanofiber-based $\mathrm{NO}_{2}$ gas sensors. Sensors and Actuators B 2011, 160, 14681472.

(23) Gao, C.; Li, X.; Lu, B.; Chen, L.; Wang, Y.; Teng, F.; Wang, J.; Zhang, Z.; Pan, X.; Xie, E. A facile method to prepare $\mathrm{SnO}_{2}$ nanotubes for use in efficient $\mathrm{SnO}_{2}-\mathrm{TiO}_{2}$ core-shell dyesensitized solar cells. Nanoscale 2012, 4, 3475-3481.

(24) Xia, X.; Dong, X. J.; Wei, Q. F.; Cai, Y. B.; Lu, K. Y. Formation mechanism of porous hollow $\mathrm{SnO}_{2}$ nanofibers prepared by one-step electrospinning. Express Polym. Lett. 2012, $6,169-176$. 
(25) Jiang, C.; Zhang, G.; Wu, Y.; Li, L.; Shi, K. Facile synthesis of $\mathrm{SnO}_{2}$ nanocrystalline tubes by electrospinning and their fast response and high sensitivity to $\mathrm{NO}_{\mathrm{x}}$ at room temperature. CrystEngComm 2012, 14, 2739-2747.

(26) Gokulakrishnan, V.; Parthiban, S.; Jeganathan, K.; Ramamurthi, K. Investigations on the structural, optical and electrical properties of $\mathrm{Nb}$-doped $\mathrm{SnO}_{2}$ thin films. J. Mater. Sci. 2011, $46,5553-5558$.

(27) Weber, I. T.; Andrade, R.; Leite, E. R.; Longo, E. A study of the $\mathrm{SnO}_{2} \cdot \mathrm{Nb}_{2} \mathrm{O}_{5}$ system for an ethanol vapour sensor: a correlation between microstructure and sensor performance. Sensors and Actuators B 2001, 72, 180-183.

(28) Wang, Y.; Brezesinski, T.; Antonietti, M.; Smarsly, B. Ordered Mesoporous Sb-, Nb, and Ta-Doped $\mathrm{SnO}_{2}$ Thin Films with Adjustable Doping Levels and High Electrical Conductivity. ACS Nano 2009, 3, 1373-1378.

(29) Leite, E. R.; Weber, I. T.; Longo, E.; Varela, J. A. A New Method to Control Particle Size and Particle Size Distribution of $\mathrm{SnO}_{2}$ Nanoparticles for Gas Sensor Applications. Adv. Mater. 2000, 12, 965-968.

(30) Petricek, V.; Dusek, M.; Palatinus, L. Jana 2006 The crystallographic computing system; Institute of Physics, Praha, Czech Republic, 2006.

(31) Brunauer, S.; Emmet, P. H.; Teller, E. Adsorption of Gases in Multimolecular Layers. J. Am. Chem. Soc. 1938, 60, 309-319.

(32) Shirley, D. A. High-Resolution X-Ray Photoemission Spectrum of the Valence Bands of Gold. Phys. Rev. B 1972, 5, 4709-4714.

(33) Scofield, J. H. Hartree-Slater subshell photoionization cross-sections at 1254 and 1487 eV. J. Electron Spectrosc. Relat. Phenom. 1976, 8, 129-137.

(34) Van der Pauw, L. J. A method of measuring specific resistivity and Hall effect of discs of arbitrary shape. Philips Res. Repts. 1958, 13, 1-9.

(35) Trasatti, S.; Petrii, O. A. Real surface area measurements in electrochemistry. Pure Appl. Chem. 1991, 63, 711-734.

(36) Kong, J.; Liu, Z.; Yang, Z.; Tan, H. R.; Xiong, S.; Wong, S. Y.; Li, X.; Lu, X. Carbon/ $/ \mathrm{SnO}_{2} /$ carbon core/shell/shell hybrid nanofibers: tailored nanostructure for the anode of lithium ion batteries with high reversibility and rate capacity. Nanoscale 2012, 4, 525-530.

(37) Li, L.; Yin, X.; Liu, S.; Wang, Y.; Chen, L.; Wang, T. Electrospun porous $\mathrm{SnO}_{2}$ nanotubes as high capacity anode materials for lithium ion batteries. Electrochem. Comm. 2010, $12,1383-1386$.

(38) Horváth, E.; Kristóf, J.; Nasser, H.; Frost, R. L.; De Battisti, A.; Rédey, Á. Investigation of $\mathrm{SnO}_{2}$ thin film evolution by thermoanalytical and spectroscopic methods. Appl. Surf. Sci. 2005, 242, 13-20.

(39) Ribeiro, T.; Sasaki, J.; Vasconcelos, I. Structural disorder of ball-milled, nanosized, Fe-doped $\mathrm{SnO}_{2}$ : X-ray diffraction and Mössbauer spectroscopy characterization. J. Mater. Sci. 2012, 47, 2630-2636.

(40) Diéguez, A.; Romano-Rodríguez, A.; Vilà, A.; Morante, J. R. The complete Raman spectrum of nanometric $\mathrm{SnO}_{2}$ particles. J. Appl. Phys. 2001, 90, 1550-1557.

(41) Gokulakrishnan, V.; Parthiban, S.; Jeganathan, K.; Ramamurthi, K. Investigations on the structural, optical and electrical properties of $\mathrm{Nb}$-doped $\mathrm{SnO}_{2}$ thin films. J. Mater. Sci. 2011, 46, 5553-5558.

(42) Themlin, J.-M.; Chtâ̂b, M.; Henrard, L.; Lambin, P.; Darville, J.; Gilles, J.-M. Characterization of tin oxides by X-ray-photoemission spectroscopy. Phys. Rev. B 1992, 46, 24602466. 
(43) Wagner, C. D.; Gale, L. H.; Raymond, R. H. Two-dimensional chemical state plots: a standardized data set for use in identifying chemical states by X-ray photoelectron spectroscopy. Anal. Chem. 1979, 51, 466-482.

(44) Kaciulis, S.; Pandolfi, L.; Comini, E.; Faglia, G.; Ferroni, M.; Sberveglieri, G.; Kandasamy, S.; Shafiei, M.; Wlodarski, W. Nanowires of metal oxides for gas sensing applications. Surf. Interf. Analysis 2008, 40, 575-578.

(45) Dobler, D.; Oswald, S.; Behr, G.; Werner, J.; Wetzig, K. Changes of Auger parameter in doped $\mathrm{SnO}_{2}$ powders. Cryst. Res. Technol. 2003, 38, 956-961.

(46) Zhang, G.; Qin, G.; Yu, G.; Hu, Q.; Fu, H.; Shao, C. Ab initio investigation on a promising transparent conductive oxide, $\mathrm{Nb}: \mathrm{SnO}_{2}$. Thin Solid Films 2012, 520, 5965-5970.

(47) Wesselmark, M.; Lagegren, C.; Lindbergh, G. Degradation Studies of PEMFC Cathodes Based on Different Types of Carbon. ECS Trans. 2009, 25, 1241-1250.

(48) Antonucci, P. L.; Romeo, F.; Minutoli, M.; Alderucci, E.; Giordano, N. Electrochemical corrosion behavior of carbon black in phosphoric acid. Carbon 1988, 26, 197203.

(49) Kinoshita, K.; Bett, J. Electrochemical oxidation of carbon black in concentrated phosphoric acid at $135^{\circ} \mathrm{C}$. Carbon 1973, 11, 237-247.

(50) Balgis, R.; Anilkumar, G. M.; Sago, S.; Ogi, T.; Okuyama, K. Nanostructured design of electrocatalyst support materials for high-performance PEM fuel cell application. J. Power Sources 2012, 203, 26-33.

(51) Zhang, P.; Huang, S.-Y.; Popov, B. N. Mesoporous Tin Oxide as an OxidationResistant Catalyst Support for Proton Exchange Membrane Fuel Cells. J. Electrochem. Soc. 2010, 157, B1163-B1172.

(52) Bauer, A.; Chevallier, L.; Hui, R.; Cavaliere, S.; Zhang, J. J.; Jones, D.; Roziere, J. Synthesis and characterization of $\mathrm{Nb}-\mathrm{TiO}_{2}$ mesoporous microsphere and nanofiber supported $\mathrm{Pt}$ catalysts for high temperature PEM fuel cells. Electrochim. Acta 2012, 77, 1-7.

(53) Huang, S.-Y.; Ganesan, P.; Popov, B. N. Titania supported platinum catalyst with high electrocatalytic activity and stability for polymer electrolyte membrane fuel cell. Appl. Catal. $B$ 2011, 102, 71-77. 


\section{SYNOPSIS TOC}

A novel complex loose-tube (fiber-in tube) morphology has been obtained for (Nb)- $\mathrm{SnO}_{2}$ by conventional, single-needle electrospinning. The mechanism of formation of such 1D architectures has been elucidated, showing that the presence of niobium significantly drives the morphology of electrospun tin oxide from dense fibers to loose-tubes. These results will allow the precise control of the morphology and dimensions of $\mathrm{SnO}_{2}$ electrospun materials through heating rate, dopant and precursor concentrations. The obtained materials have been characterized by electron microscopies, thermogravimetric analysis, Raman spectroscopy, XPS, and XRD. Furthermore, electrical conductivity and specific surface area measurements as well as accelerated corrosion tests and electrochemical measurements for Pt loaded materials show that $\mathrm{Nb}$ doped $\mathrm{SnO}_{2}$ loosetubes are promising electrocatalyst supports for fuel cells.

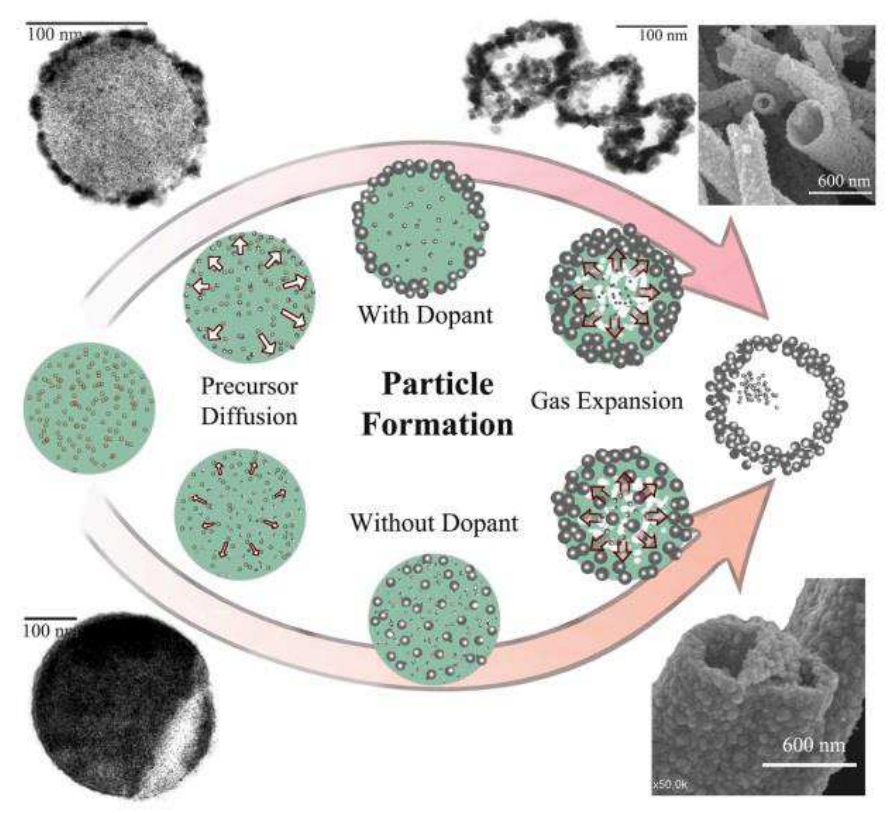

